\title{
Dissident Bodies and Migrant Hogra among Young Maghrebi during Two Years of the 'Arab Spring' (Tangiers 2011, Morocco; Turin 2010-2013, Italy).
}

\author{
Alice Rossi \\ Doctoral School of Human Sciences - Anthropology of the Contemporary, \\ University of Milan - Bicocca \\ E-mail: a.rossi30@campus.unimib.it; rossalice77@yahoo.it
}

\section{Doi:10.5901/mjss.2013.v4n11p58}

\section{Abstract}

The immense so-called Arab Spring mobilization suggested a politically-produced process; created by contingent dimensions and fluent coalitions that influence the current migration dynamics and policies in Europe. The present contribution is part of a multi-local ethnography effectuated in Morocco (Khouribga 2007; Tangiers 2011) and Turin among the ultimate-decade's Moroccan immigrants and Tunisian migrants from the so-called North African Emergency. During summer 2011, Moroccan media renamed Tangiers: 'People's Capital of the 20 February Movement'; depicted as young and new, albeit heterogeneous in age, genre and of socio-political appurtenance. Furthermore, the last decade has witnessed populace protests throughout Morocco; particularly in small, medium-sized cities like Khouribga; emigration springboard towards Turin since the eighties. Here the $20 \mathrm{~F}$ movement redefined and integrated itself with local-migration policies. Crucial, politically-related events within an intimate and familiar sphere - concomitant with intergenerational, social breakdowns and continuity amplified by emigration will emerge through life-stories. Migrants, both in Tangiers and Turin, criticize the hogra as standing for vulnerability and a lifestyle when confronted by power. My analysis shows how this sentiment - publicized during the Arab Spring, but rooted in Moroccan history - emigrates by accompanying people, who encounter growing migration-policy and life-condition difficulties in a new context. In conclusion, I will show how corporeity can transmute into a manipulatively exploitable power-element; culminating in individual and collective violence. This occurred both during Tangier's movement and in Turin amongst Tunisian Asylum-seekers and migrants held within the CIE (Centre of Identification and Expulsion).

Keywords: Imagery and Practices of Dissent; Secular and Religious Movements; Maghrebi Migration; Hogra (humiliation); Corporeity; Violence.

\section{Introduction: A Succinct Historical Prospective of Contemporaneous Dissidence in Morocco}

The 20 February 2011 Movement in Morocco had been preceded by multiple protests by the populace (Al Hoceïma, Khenifra, Sidi Ifni, Beni Mellal...) during the last decade in different zones of so-called 'useless Morocco'1 (Bennafla; $2009,2010)^{2}$. In the past, as also nowadays, cases of violent repression and censorship are manifest even in the face of pacific forms of dissidence.

Nominated by the media and the Moroccan activists with the date reminiscent of the first manifestation that was diffused throughout national territory, the Movement had been influenced by its impact with the Arab Spring; criticizing the Country's ramified corruption and demanding the breakdown of absolutism. During the course of 2011, the official Press, which sustained the theory of Morocco's Exceptionalism, discredited the Movement by likening it to Fronte Polisario ${ }^{3}$ (García; 2011). It, furthermore, attributed acts of vandalism to the Movement with a negative sway on public opinion.

\footnotetext{
${ }^{1}$ The distinction between useful and useless Morocco dates back to the colonial period in Morocco..

2 In Karine Bennafla's opinion, engaged with political geography at Jacques Berque Center in Rabat, these mobilization movements, which became the subject of the workshop 'Fabrication et sens des marges au Maroc'(2009), have a socio-economical, political character, as it appears from the specific focus on 'les mobilisations de périphérie au Maroc: les cas de Sidi Ifni et Bouarfa'. All the episodes express the collective exasperation towards the deterioration or mediocrity in living conditions, towards the abuses by the authorities, the indifference and the oblivion in front of popular poverty. From Karine Bennafla's analyses it appears that - if movements initially have pacific expressions (hunger march, sit-in...), their evolutions are very unpredictable and the repressive machine acts in the same manner, establishing an emergency status and resorting to arrests, searches, trials and detentions; as is the occurrence in contemporary protests..

${ }^{3}$ It is an army and a political movement active in Western Sahara; it represents the Saharawi people's right to self-determination.
} 
The first part of the present contribution concerns the context of Tangiers, particularly so one of its quarters, Beni Makada, a popular zone notorious for its insubordination ever since the times of contestations against Hassan II. This urban context suffers a governmental, investment deficit, which has been accumulating since the fifties and is rooted within the history of North-Moroccan ${ }^{4}$ dissidence. At Beni Makada in the square of the cinema Tarek, renamed as the square of 'change', the first manifestations of the Movement were organized.

To historify the constructive process of protests despite official rhetoric towards the process of democratization of the new Morocco - central theme at the end of the reign of Hassan II - more analytical levels need to be taken into account; starting with the voice of those that have participated and with special consideration for activists' types of credence and practices (Geertz; 1968).

"We won't give in (mamfakinch)"! This is one of the past and present slogan of the demonstrators in Marocco. It is also the name of the site ${ }^{5}$, where the mapping of protests had been published instantly and where copious documentation had been filed; inclusive of the irregularity of the constitutional referendum (01.07.2011), of the Makhzen's 6 intimidating methodology, which has been used to exploit the media, imams, brotherhoods and demonstrators paid by the king (baltajia ${ }^{7}$, royalistes...). The website asserted that it was not a matter of a "plebiscitary victory" but a "cosmetic reform" conceded by the king, who should be "reigning instead of "governing". If the website is a novelty, student protests instead date back to the struggles of the Students' National Union (UNEM); a clandestine movement, which has been violently repressed for the last three decades.

In fact, since Independence (1956), the scholastic-education environment has been representing an arena of conflict between the political regime and the population. During the course of the seventies, the politics concerning the exploitation of Islam, which targeted the schooled youth as an objective (Gandolfi; 2010) had led to discussions of "reIslamizing society" (Vermeren; 2002). The gradual process of "re-inventing" religious tradition (Tozy; 1999), combined with the territorial-unity concept - emblematically represented by the famed "green march" ${ }^{8}$, has consecrated the effective hegemony of the monarchy. The official rhetoric, the repression and control over the students' environment ${ }^{9}$ contribute to the formation of that which Foucault defined as the practices through which you construct the subject. These practices themselves are not something the individual creates on his own but they are constructed in accordance with schemes that are proposed and suggested; imposed upon the individual by "his" culture, "his" society and by "his" group ${ }^{10}$ (Martin, Gutman, Hutton; 1988).

In the past, student uprisings have been renamed and "publicised through the media" as "bread revolutions" applying the use of a depoliticized lexis, which has concealed the socio-economic and political reasons for these struggles. In the summer of 2011, the Press described Beni Makada as the capital of the 20F Movement in virtue of the massive adhesion among members of the populace, while it did not examine possible links of profound roots with the Jamaâ d'Al Adl Wal Ihssane ${ }^{11}$. Islamic Group; especially so, orientated towards recruitment and training within the ambience of the more marginalized classes. Moreover, the 20F Movement - as I intent demonstrating - is involved within a rhetoric that postulates 'Novelty'; thus negating the historicity of claims and determining the emergence of a moral economy (Fassin, 2009; Thompson, 1971; Scott, 1983), which represents a young movement without roots in the past.

\section{The Tangerine Movement: 'Atheist-traitors and bearded-Islamites'}

"one of the reasons this series [of techniques of the body] can be mounted in a more facilitated manner in the individual consists precisely in the fact that they are assembled by/and for social authority"(Mauss 1934, p. 407).

\footnotetext{
${ }^{4}$ During the Rif war (1921-1926) against Spain (and later on against France and the very King of Morocco), the Emir Abd El-Krim ElKhattabi declared the Republic Confederation of Rif tribes.

5https://www.mamfakinch.com/

${ }^{6}$ Vernacular term indicating the power-net of the central Government.

${ }^{7}$ Delinquents.

${ }^{8}$ The march led by King Hassan II in 1975 in order to cross the West Saharan border; at that time autonomous, Spanish territory, disputed by Morocco against Spain..

${ }^{9}$ The Association Nationale des Diplômés Chômeurs (ANDC) has to be mentioned among the more represented components of the present student movement

10 In "Self-technologies" (1988), its authors -Luther H. Martin, Huck Gutman, Patrick H. Hutton - face the Foucault treatise of sciences meant as very specific "truth game", linked to particular techniques human beings utilize in order to understand themselves (p. 13). Four technology-types have been individuated (of production, sign system, power and oneself), interrelated and associated to particular supremacy forms, which imply specific methods of education and modification of the individual (p. 13-14).

11 In French Justice et Charitè;, in its own activists' opinion, there are 3 million supporters in Morocco.
} 
In the next few ensuing paragraphs, I intent showing how "dissident bodies" are objects-subjects of more or less symbolic, violent practices. During summer 2011 the language of the media has, in stereotypical fashion, renamed leftist dissidents 'atheist-traitors' and Islamic activists 'bearded-Islamites'; re-proposing a political, cultural and religious dichotomy between secular-French-speaking modernists on the one side and Islamic-Arab-speaking traditionalists on the other side (Jerad; 2012) ${ }^{12}$. Nonetheless, it has to be kept in mind that, during my multi-sited research, all activists encountered by me defined themselves as Muslims independently from their political adherence. The current conflict appears rather to emanate from the diverse interpretations of being Muslims. To this effect, it is interesting to observe the manner in which they produce various models to give form to the modern, Muslim self (Osella, Soares, Salvatore; 2010) in contexts of social activism and migratory mobility. As I could notice in my different fields, heterogeneous emerging embodied forms of life prevail over dichotomous view on religion and secularism (Asad; 2003).

Hence, it has been my option to take recourse to the metaphor of dissident bodies; in that the body represents the place in which the individual gets regenerated through a practice of the incorporation of history (Fassin; 2001), which - in this specific case - reveals paradoxes of contemporaneous dissidence. I, therefore, started with the examination of bodies, both as a primary, experiential dimension and as territory in which the subject's complex, identity dynamics take form; three plaited poles that are inextricably connected; the social, psychological and the political as perfect machine-àcomuniquer and similarly so impeccable machine-à-penser (Scheper-Hughes, Lock; 1987; Csordas, 1999). Therefore, activists' rhetoric can be better defined as 'embodied words' which reveal how bodies themselves are the visible arena of intersecting different (invisible) forms of power which became visible in the contradictory relationship between subjective experiences and social processes.

Indeed, by comparing the activists' rhetoric with their practice, it appears that left-wing "atheist-traitors" and "bearded-Islamites" shared manifestations during the course of 2011.

In the opinion of Mohammed, a Moroccan activist of the Leninist formation: "It's counterfeit love; a created compromise to resist the confrontational oppression exerted by the monarchy and the hogra." (11 July 2011). Simultaneously though, the perception of the activists was that of it concerning a political macro-design based on the capacity of the Makhzen to currently capitalize on its own dissidence in the same way as in the historical past.

During the elapse of 2011, the Movement had to confront the handling of complex relations and contradictions involving political and social entities of great diversity, like the Islamic group Justice et Charite forbidden but tolerated by the government, or the La Voie Démocratique party.

At the end of 2011 (18.12.2011) Justice et Charité has left the 20F Movement and this has caused a reduced participation. In the public communication, however supporting the struggle's claims, the Islamic group has evidenced the internal difficulties linked to the fragmentation of the movement; with the invitation aimed to the International Community not to support any despotic regime .

Whilst allowing for dialogues amongst voices of activists from distant political derivations, I will concentrate on their testimonies.

Amid ${ }^{13}$, a thirty-year-old activist, was born in the quarters of Beni Makada and lives there. He has relocated to Morocco, where he is presently occupied in the ambience of social assistance after having been a migrant in Spain. Ever since our first meeting, he had stressed his free-will to return and "to fight for change in his country". But today he is no longer convinced of anything subsequent to firsthand experience with the heavy-handedness of police repression; "embodied memory" (Beneduce; 1998) within the corporal evidence of scars and with which Amid lives his intersubjective rapports (Passerini; 2003) with his family terrorised by his role as an activist. According to his parents, he is an unfaithful enemy of the king, who is father to all Moroccans Amid's political comportment falls within the sphere of haram (illicit); mining his relationships with elderly parents. Haram, in fact, is a religious term, which means prohibited and is the antithesis of halal (permitted) and with which to share its dimension that combines religious discussion to that appertaining to the family. According to an Islamic precept, Haram is the position of a transgressor; in that whoever exists as such activates a sort of curse, sackt, at work on the part of the entire family ready to assail and disown the perpetrator. On the contrary, halal is the accepted position, which is embraced to redeem family membership and relations by restoring a blessing, r'da (Rossi; 2012).

Regarding this subject, the liaison between power and subject needs consideration (Foucault 1980; 1982), which I intend examining in its double meaning of subject/subjected (Foucault 1976; 1988). Judith Butler has performed a detailed analysis on that disjunction; defined by her as "the paradox of subjectivity", for which the processes and the

${ }^{12}$ Still today, the multi-lingual scenario in Morocco reflects different statuses, meanings and the social uses of local dialects; the classical Arab and French ones.

${ }^{13} \mathrm{All}$ names utilized for activists are fictitious. 
conditions that ensure subordination, end in guaranteeing the same possibilities of self-consciousness and action. This is at the bottom of the subjectivity/subjugation process, which the activists of various political affiliations describe with regard to their fear of checks; to a condition or mental state of "war" (Mbembe; 2005) and permanent alert; implicating suspicion and 'paranoia' since anyone could be a government informer.

Amid "...It's not a matter of physical violence only but also that of psychological pressure; a sense of diffused humiliation (hogra); threats that impress through the king's power with fear of control and repression" (meeting 25 June 2011). Amid appears rather suspicious about associations and parties: "Checks are diffused; there are infiltrators everywhere..." he expounded to me one day, "I have a friend in the police force. We are distant in political positions but respect each other. He told me that in Rabat, on occasions of manifestations, the police get orders with real mandates from their overseers to involve their family members by sending them to form a movement against the 20F Movement; to this effect the wives of the police have been influenced to realize this! Also their friends have been mobilised to give the YES vote at the referendum of constitutional reform (meeting 05 July 2011)".

For a few years now in Tangiers as well as in Beni Makada, a process of re-qualification and development has been running via the logic of reforms. From the activists' viewpoint these are more concerned with general rhetoric pertinent to the process of democratization and of cooptation of power nowadays; like matters were during the colonial epoch.

According to Hibou, political economist at SciencesPo, CERI CNRS (Paris), it was not a question of a process to democratize but rather that of the pluralisation of relationships concerning power, which has opened space for liberty and places for debates; amplifying possibilities of handling and quelling conflicts (2011; 2009). The authoress emphasises that this anti-political dynamic has converted itself in Morocco as on a global level in two ways; one via technocracy, which accentuates the neutral apolitical aspect and the other via the development of associative means; thus translating it into the handling of discontent through partial resolutions to a few problems (Hibou; 2011). The politician's discrediting movement, contributes towards the translocation of the politician's 'battlefields' to non-battlefields without polemics and conflicts; new arenas of power; like development agencies, committees and the associative world. Hibou $^{14}$ is of the idea that the present moment is characterised by 'a way of thinking which prohibits itself to think'; in which the participation rhetoric becomes a technique concerning domain. The associative world at Tangiers represents the link with old and new political entities. Mohammed, a militant member of the Attac ${ }^{15}$ organization, reckoned that skirmishes between left-wing manifestants and Islamites often in disagreement about where to end processions - as I personally have often observed - involve a political strategy, which is nothing new and dates back to the latter part of Hassan II's reign. Moreover, the rhetoric of the historical novelty is functional to emphasize disseverance from the past. If this on the one hand allows the 20F Movement to eschew the inheritance of certain historical, clandestine, left-wing organizations (Adelante, Trabajar para el pueblo, $23 \mathrm{March}$ ), on the other hand it consents to the Makhzenitan apparatus breaking with the heavy years and repressions through the media.

"Today like yesterday," said Mohamed, "ideological pressure consists in defaming opponents even among relatives; infiltrating within their families, who continue to be subjected to the sense of being threatened and live the terror of possible violence against their children and the disgrace of being labelled 'parents of traitors and atheists...this is haram! The people believe that the king is like a father!" (10 August 2011).

Reflecting on the cultural-religious bases of maestro-disciple relationships, Hammoudi (2001) describes the way in which this model transforms into absolute power on the one side and an attitude of submission on the other side; that of the disciple renouncing to his 'ego'. According to this prospective, the hierarchies that from the micro to the macro concern the structuring of the entire society (family, schooling, work, the State) reflect these said relations, which nowadays are reiterated with the envisioning of the King as the father-figure described by various activists when referring to relationships with their own parents.

In order to comprehend the manner in which Moroccan society interprets its rapport with authority, one needs to make reference to the principle of uniqueness of monarchical power, of which God represents perfection (Tozy; 1999, $p$. 51). Hassan II's conception of power is an example of an invention of tradition (Hobsbawm, Ranger; 1989), which through rehabilitation of the bay'a (ceremony of an alliance) has legitimated the idea of a power that attenuates the importance of negotiation forms; thus preserving and revamping the ritual of subordination between the people and the king/sultan (Hibou; 2011). The appearance of an Islamic flow has accelerated and transformed this process, which has transmuted from a traditionalizing project to the revival of tradition; the room for sacredness has become unlimited

${ }^{14}$ On the occasion of the Cinquième Rencontre européenne d'analyse des sociétés politiques (REASOPO, Paris), "Printemps arabes: mythe et fictions", 2-3 febbraio 2012.

$15 \mathrm{http}: / / \mathrm{www}$.attac.org/ 
(1999).

Even nowadays, public exhibition of sacred power gets renewed and celebrated in the same way it was displayed during that intensive campaigning week for the 'YES' in anticipation of the constitutional referendum 16; or, on the occasion of the Coronation Celebration (30 July 2011), when the 20F Movement's date was shifted and the annual concession event of 'grace' - on the part of Mohamed VI - was bestowed upon political prisoners.

A woman in charge of the National Political Office of the Islamic Movement ${ }^{17}$, Jamaâ d'Al Adl Wal Ihssane, had an interesting tale to relate indeed amongst all those witnesses encountered during my camp of 2011 in Morocco.

Initially, this director had listed a lengthy series of intimidations she was subjected to on the part of the Makhzen: Domestic irruption perpetrated by men without their uniform; the defamation of her daughter in a local newspaper; aggression suffered by another daughter while returning from school; and the bankruptcy of her husband's work. Alongside her recounts, the theme of taking recourse to the exploitation of inter-generational relationships repeats itself. In fact, during one of her journeys in Spain, some men had asked her elderly father to call back his 'daughter', who - as far as they were concerned - was in Spain on a mission. Off-spring, their parents and grandparents are involved in the dynamics of terror that are created; thus in the victims the need of defence becomes radical. This director, in fact, with regard to the militancy of her daughters spoke about the 'the boomerang effect' and elucidated that "[...] during the referendum campaign, because of the accusations of atheisms hurled at the Movement, the Imams were compelled by the minister of Religious Affairs to preach pro-referendum sermons. Accusations of atheism target emotions.... it is haram! Hence, the youngsters had decided to break their fast in unison after the fourth prayer of the day, the Maghreb... it was a symbolic gesture to defend themselves from the humiliation (hogra) of these accusations. Even the inhabitants participated. It was convivial indeed. Their objective is to turn the people against the 20F Movement by transforming a social struggle into a religious war. It's the same policy exploited by Hassan II; that of instigating antagonism between the left and the Islamites" (11.08.2011).

While employing a lexicon that naturalizes the presence of Islam in the 20F Movement, this militant elaborated on their participation as being spontaneous in that their work concerns social justice; the right to dignity, teaching, nonviolence through two levels of action; one which is educational/spiritual the other social/communicative. From her viewpoint, it does not concern an illegal organization; they are not Islamites but Sufi-devoted Muslims; though they criticise an attitude of passiveness and claim the need for action.

The director's recount delineates the 'look of power' of a panoptic type (Foucault; 1975) as that authority of Surveillance and absolute control over the body, on which the possibility of visibility is dependent; as in the prison described by Bentham (1786), who had coined the term 'Panopticon'. "Here we say that 'walls have ears'! You can't be of service to others because you're afraid of others. In Morocco, you need to fear things: fire; the sea and the Makhzen!" (11.08.2011).

\section{The lexicon of the migrant Hogra}

"Subjected to the Hogra means to be vulnerable. It's not a question of age but that of position in front of the power" Bigg (rapper from Casablanca)

The migratory issue, linked to French-Spanish, colonial remnants, inherited in terms of dependence - even though only in various forms, has never really ceased but poses another crucial element representative of indisposition and that sense

\footnotetext{
${ }^{16}$ The 'new' constitution, voted by a presumed majority, which does not reflect the real participation (considering that only $44 \%$ of the rightful voters collected their voter registration card) reasserts the commanders' statute of the believers, personalized expression of this hegemony, which allows for a symbolic and spiritual dimension to overflow and supports a political, exclusive system. In Hammoudi's words: "as a descendent of the Prophet, the Monarch - in the eye of the people - embodies his ancestors' miracle: the apparition of a community, which restores a Primordial Word and the order founded by it. For this reason, this lineage - by God's will, placed above all others lineages - has the right to transcend all the differences" (2001; p. 34).

${ }^{17}$ During 2011, the main Islamic presence in the 20F Movement in Tangiers was that of the Jamaâ d'Al Adl Wal Ihssane organization, established in the eighties; founded on obedience (sufi) and corporativism. Its structure cannot be divorced from the central role of its founder and leader Abdessalam Yassine, who lived as a Saint and was described as a 'genius' even by his opponents. The movement is related to another type of syncretic Islamism, which associates the mystical dimension with the political one. During the testing period, the initiate-supporter (nacir) has to sustain the movement - for instance - by attending public demonstrations. Supporters gathered during public demonstrations in order to create a mass-effect; with the aim of frightening political competitors (Tozy; 1999).
} 
of humiliation (hogra) ${ }^{18}$. In contexts of a high emigration rate like the frontier-city of Tangiers in the North - privileged destination of rural exodus from Rif - or South in the region of Souss-Massa-Draâ at Sidi Ifni, where since 2005, a collective has been constituted by various political forces and associations; the common objective of protests being the defeat of marginalization. During the decades of the eighties and nineties, when the migratory phenomenon was transformed into a structural component of relationships between Maghreb and the European Union, the portal city of Tangiers with an 'international statute' (1923-1956) and historical frontier towards Europe, had become one of the principal borders for clandestine Moroccan emigration and subsequently also that of sub-Saharan regions ${ }^{19}$.

Migratory mobility can also be a factor of diffusion for protests in Europe. This is what actually happened in Turin (North Italy), where the 20F Movement had sprung up; all thanks to the creation of the trans-national networks (Vertovec, 1999; Riccio, 2008) following the massive exodus from the provinces of Khouribga and Beni Mellal; the aftermath of the 'phosphate crises' of the eighties. On the other hand, Moroccan immigrants, resident in Europe (MRE), represent an electoral potential for a future migrant political party; already in the air as a positive form to take charge of dissidence.

Turin, as an industrial city in North Italy, used to be regarded as one of the destinations privileged by immigration from the South of Italy. Today it is amongst those enticing places that attract immigrants not only, especially so, from sub-Saharan regions but also from Tunisia, ensuing the so-called North African Emergency. Moreover, it is a city steeped in a long history of social activism of Marxist and anarchical orientation; related to migrant activism through networks of numerous Occupied Houses and Social Centres found in the metropolis. Tunisian immigration is not a recent phenomenon. Since the seventies, the influx of Tunisian emigrants towards Europe has been waxing noticeably and Italy happens to be one of the main countries of destination for Tunisian workers that take the plunge to go abroad (Gigliotti; 2005). Resident migrant networks have contributed towards welcoming compatriot-refugees, who had fled from the socalled 'Arab Spring'; they intervened whenever the efficacy of institutes proved over-challenged.

The testimonies that follow are a few voices I had the opportunity to listen to after a lapse in my research when silence was prevalent. In fact, what then ensued my camp experience in Morocco was my persistent search for opportunities to make the acquaintance of Moroccan and Tunisian migrants. But for several months no headway for testimonies could be made; neither on the significance of the Hogra, nor on the events pertaining to the Arab Spring. It had become virtually impossible to get people to speak, particularly those, who had been subjected to traumatic experiences during the revolution in Tunisia, or following their emigration; once they were detained in $\mathrm{CIE}$ - Turin notwithstanding their request for political asylum ${ }^{20}$. Hence, starting off with reflections by Franco Basaglia and Frantz Fanon, who, on re-organizing themselves at an epistemologically accurate and politically comprehensible horizon, redirected my search for the social sufferance (Kleinman, Das, Lock; 1996) of street juveniles; dissidence in its deafest and most obstinate form; these youths being critical of social order, authoritarian rapports and violence. In any case, considering the street as a place of 'choleric' expressions and of rebellion, my questions were also addressed to a few juvenile Moroccans, whose acquaintance I had made within my work ambience as a social worker. This occurred whenever clandestine minors arrived in Turin unaccompanied in 2001, 2002. Often their response to me simply asserted their total support for the King of Morocco. But there were also those, who lauded the old policy of Hassan II (19611999): "Hassan II once said: If you have something that proves you're Moroccan, you can be repatriated, otherwise no" (interview 16 March 2012). With regard to street culture, Bourgois (2005) demonstrated how this situation turns out to be a factor of personal degradation and destruction of the community in a final analysis; despite it emanating from the individual's desire for dignity, the rejection of racism and of subordination. Such individuals thus contribute to the formation of oppression; exposed as they are to the vastest of social dynamics (Bourgois, 2005).

${ }^{18}$ The hogra feeling expresses the humiliation inflicted through power abuse by old leaders; via contempt and arrogance of the authorities.

${ }^{19}$ For further information on border towns and transmigration studies, refer to Ali Bensaad's and Ruben Gielis's works.

${ }^{20}$ On the appeal signed (06.12.2011) by numerous Italian associations with the 'Request for granting permits on humanitarian grounds to those fleeing the war', we read: "Following rebellions in Northern Africa and the surging war in Libya, since the first months of 2011, arrivals of people in great numbers on Italian coast had been witnessed; fugitives, who left Tunisian and Libyan coasts but hailed from various African countries. After declaring the emergency status on the national territory - initially meant to finish 31.12 .2011 - the Government in charge at that time decided to grant permission to stay for 6 months on humanitarian grounds to those North African countries' citizens, who inundated the national territory from January 1st 2011 to midnight of April 5th, 2011. Differentiated treatment had been applied to those migrants, who arrived after April 5th. Thousands of Tunisians, in fact, were forced back at the borders, whilst other migrants, arriving mainly from Libya but with credentials of different citizenship, were allowed to present - in a quasi-automatic manner the request for international protection. Nevertheless, great numbers of said requests for international protection were rejected by territorial commissions; accompanied by wording of rejection which appeared ready-made; no motives were expressed that adequately took into account the circumstances relating to a war-ridden country". 
My endeavour was also to explore the dimension of conflict behind the silence, obedience and immobilization. That which emerged was discordant subjectivity; as if the memory - once emigrated - splits up between past life and present life; as if there were apparently no connection. What emerged via their recounts were differences in timing, fragmented perceptions of their Country and some of them described the uprisings of the Arab Spring as if they were talking about a post card; of a remote envisagement.

I have stumbled across a possible key regarding this distorted perception and fragmentations by reading the analyses of Kleinman (1986) on depressive syndromes; generated through frustration and violence during the Chinese Cultural Revolution. Also in the case of those migrants I had occasion to meet in Turin, their auto-reflexive difficulties could be interpreted as the sign of a device that impedes the individual from executing certain connections. Apropos of splitting and dissolution forms related to the conditions of the colonized individual, Fanon $(1952 ; 1956 ; 1961)$ wrote that these conditions favour the stability of the colonial dominion. An approach directed at denaturalizing the processes and techniques of the memory can be gathered from the anthropological look, which has already evidenced how we imagine the past and remember the future (Quaranta; 2007). The past is, in fact, an unstable terrain of cultural moulding and political confrontation.

In the specific context in which I am occupied, you may refer to a process of migrant, political de-subjectivity (Fassin; 2001) or, as Hibou has written, a configuration, which the authoress defines as anti-political. The migrants' political capacity is annulled by the burden of the individual dimension related to a condition of life legally regulated similar to that of homo sacer (Agamben, 2005) ${ }^{21}$. In the case of Turinese migrants, today's "sacred men", the analogy is with the State that regard those arrivals of individuals in Italy after 5th April 201122 and then their requesting for political asylum, as clandestine economic migrants legislating within the double meaning of inclusion-exclusion. What it entails is a kind of thanato-politics (Martin, Gutman, Hutton; 1988, p. 151), which manifests itself in the form of violence on the part of the police; involving deportations, zero tolerance (Wacquant; 2004) within the internal detention of the so-called C.I.E. and within the continuous and rather deliberate oscillations on the subject of immigration.

For these reasons, I lingered over what I have synthesized in the expression hogra migrante (migrant hogra); the feeling of humiliation in the emigration-immigration continuum. In fact, the term hogra not only recurs in the media; but during my research, I have encountered it often among Moroccan activists and Maghrebi immigrants living in Turin. The diffusion of this term beyond the national borders of various Countries in North Africa, like Morocco and Tunisia, is strictly related - at least so in the West - to the mediatic covering of the Arab Spring. It is a vernacular term, which appears to have survived a process of trans-nationalization with different forms of local appropriation and which has acquired a higher visibility in the public sphere. This directly implicates the European trans-national migration, the global, neo-liberal, political economy and the growth of European Islam as strictly intertwined phenomena; contributing to the transformation and creation of representations, manifold identities and plural forms of spirituality, religion and laity.

The meaning of hogra has the concise capacity of expressing a common, collective feeling, which overcomes religious-secular dichotomies, perhaps outlining one of those post-secular configurations of which this very 20F Movement appears to be the most recent expression. I am not referring to post-secular notion (Habermas, 2002, 2006; Casanova, 2009) as the completion of the secularization process, but as the coexistence of various, secular and humanistic religions (Beaumont; 2010), or rather an organizational and conceptual sphere in which post-colonial themes had their development.

Further on, through various stories, different interpretations of hogra will emerge. As a matter of fact, we are dealing with meanings which are, at the same time, common and subjective, contingent, variable; depending on the context and the type of relation I managed to instil with my interlocutors during our meetings.

\subsection{Amid, 22 April $2012^{23}$}

"[...] Hogra is Moroccan dialect; it means humiliation, when you find yourself under conditions in which you don't recognize yourself; an unbearable situation. For me, Hogra is a wonderful synthesis derived from various languages on

\footnotetext{
${ }^{21}$ In his text "Homo sacer. The sovereign power and the naked life", Agamben quotes Festo's word about this figure in the Roman archaic law:,,Sacred man is, however, he, whom the people judged for a crime; and he cannot be legitimately sacrificed, but he, who kills him, shall not be convicted of homicide. In fact, in the first tribunal law it was cautioned that "if someone should kill him, who is sacred for plebiscite, shall not be considered a murderer". From this it is derived that an infamous or impure man is usually called sacred." (Agamben, 1995, nota1 p. 79).

22 Reference in footnote 25.

${ }^{23} \mathrm{~A}$ Marxist militant, immigrated towards France but passing through Turin.
} 
this side of the Mediterranean; it expresses rejection and the struggle, as in the slogan "NO to hogra". Where it concerns me, it is not a program, but a term allowing for mutual recognition mutual amongst people; a mobilization vector".

The term hogra appears in Amid's words as a "linguistic act", a true political, pragmatic act (Austin; 1991), which characterizes the subjects' senses of belonging, since it is part of that process of word appropriation in the public sphere occurred through the Web and in the rallies, yet without representing a homogeneous space. The dialectal use with reference to "rejection, to struggle" against the abuse of institutional powers, generally associated with classic Arab and colonial French, appears to be intentioned towards expanding the socio-linguistic sphere. Both in Morocco and in Tunisia, the 0 derja dialect is the commonly-spoken, daily language in families, relationships and in more frequent social exchanges; their mother-tongue. It is through this that in the referenced social context, which unites the humiliated majority, it is expanded; almost with the aim of exorcizing the regime-derived frustrations and traumatisms starting with the overthrowing of the conventional, multilingual model, in which standard Arab and French are the dominant languages with official communications. The fact of publicly mentioning fear, perhaps allows for the softening of its impact. Hogra exists in the collective memory (Halbwachs; 1968) in Morocco, but, whilst it once used to sound familiar only in a dialectal ambience, this term has today penetrated its lexical and social borders; establishing itself as being a slogan and a political act concomitantly. Deducing from Amid's assertions, it appears that the sense of belonging determined by the feeling of hogra is based upon that denial of self-identification within a specific situation; thus a kind of identity in the negative which, through trauma revivification - as in the mechanism of traumatophilia - creates the possibility of affiliation, that of belonging (Beneduce; 1998). The practice of traumatophilia - wishing to resort to an anthropological category, which restores some agency to the subject - expresses the subject's rifts, new expressions of desire, and the crisis of social bonds (Beneduce; 2007). It is a practice which expresses the attempt at granting literacy to a social difficulty; a gesture of protestation, of disobedience and rebellion. In this sense, we can speak of a sort of infinite simulation of death and renaissance, through a traumatic act of regressing to - and bouncing back from - a chronological zero each time.

\subsection{Khalid 19 May 2012}

He is a Marxist militant, who immigrated to Turin in 2008. He declares himself a 'basist'24, that is, a Marxist-Leninistmaterialist and atheist.

"In Turin, the 20F Movement (he has explained to me) gained impetus around Justice and Charity, with the presence of some independent or autonomous members who, however, both here and in Morocco, are often connected to the Secret Services system rather than to anarchic ideologies; they are spies. In Turin, therefore, the existence of an internal contradiction between the revolutionary leftwing on the one side and the leftwing and reformist Islamists on the other side, had never been founded. Generally speaking, immigrants are neither here nor there. They are well treated by the Government because they contribute remittances. They do not participate because they lack economic and social interest. They are not simply a case of fear..."

In Turin, the Yassin movement is considered neither illegal nor an "Islamist lair". On the contrary, it enjoys an advantageous position in relation to local institutions, with which it actively cooperates. Taiba, the Alps Mosque, it's a cultural center, and is a reference point for all Muslim migrants. Tariq Ramadan, a nephew of the founder of the Association of Muslim Brotherhood in Egypt, is one of the thinkers, who gets suggested as such amongst reference authors in the field of Islamic Reformism; in favour of a European Islam².

"Hogra applies to any type of humiliation" continued Kalid. "It is also used among kids when they make fun of one another, but in a common social sense, it is indicative of the relationship the individual feels with the State. It is social, collective hogra, which people identify the moment they become aware of their rights being violated; for instance, when a policeman slaps your face. It is a common feeling among the poorer masses; among youngsters. Reactions can differ; for example, there are these suicides through the fire... They represent a sacrifice, not just a form of protest, because the risk of dying exists. It means to deny life, to refuse it, not life in itself but one's own life. For me, it is neither halal nor

\footnotetext{
${ }^{24}$ It is a non-reformist but revolutionary trend, well-rooted at the Fes University in Morocco. Its militants differentiate themselves from the Voie Démocratique Party, which is considered to be moderate and reformist.

${ }^{25}$ Author of To be a European muslim, Newton \& Compton, (1999), It. Ed. (2002) Essere musulmano europeo, Forewords by Stefano Allievi, ed. Troina (En), Città Aperta.
} 
haram; I'm an atheist. In my opinion, they are weak; from an economic and intellectual viewpoint. They are anonymous, who gain recognition. It is not they, who look for a spectacular popularity. We bestow prestige unto them. They are neither like Kamikaze, because they killed themselves for an organized, political reason, nor are they like the similarly well-organized Jiadists. For example, the first girl, who set herself alight, Fadwa Laroui26, close to Beni Mellal, was 23 or 24 and used to live in an area of shacks. She was divorced and enlisted as having the right to receive State ground onto which to build herself a house. Yet, it was never given to her. After having complained in vain, she set herself on fire in front of the City Hall. These are the psychological dynamics that surge; they have to do with social conditions; an economic dearth, desperation...! Nonetheless, in my opinion, these suicides have not created anything as they are devoid of coherence of interpretation, which depends on political interests of that current moment."

Burning suicides seem to be the ultimate expression of affiliation possibilities that have failed miserably; of powerlessness in planning one's one future. They comprise mostly young men, who can become neither fathers nor husbands, nor can they hope to become workers, who in Italy, as in their Countries of origin, live under conditions of social and moral death (Kleinman; 2011)27, of no acknowledgement of their being socio-economic and political subjects. Suicides may be interpreted as a reaction strategy by people facing the powerlessness in organizing their experiences and, more in general, in giving a meaning pattern to events which have none, or in promoting an opportunity of collective reprocessing. It is a trans-objective problem, which deals with psychical, collective transformations, produced by structural violence (Farmer, 2003; 2006) or by terror, as in the contexts pertinent to the reproduction of violence as in the ex-colonial Countries.

If "burning the borders" 28 is the metaphor which, in Moroccan and Tunisian dialects, translates the risk of dying during illegal immigration, burning one's own body is the result of "thanato-politics", which can be re-produced and "consumed" on-line. Suicide appears as a strategy of extreme manipulation of one's own body in order to obtain power which, even after death, will serve to focus attention onto one's personal events, hoping that perhaps some help for involved family members, left behind, will be achieved.

The turning into a show (Debord; 1967) of these violent deaths was launched by Mohamed Bouazizi's ${ }^{29}$ suicide. Which became notorious because it preceded the Tunisian revolution. The diffusion of images and videos of "human burning" is a component not to be neglected in the "burning suicide wave", that have been occurring during the last two years. As a matter of fact, not only in Morocco and Tunisia, but also in Italy, Maghrebi immigrants and both Italian entrepreneurs and workers ${ }^{30}$ took their lives in this way because of the current global, economic and social crisis.

By conducting dialogues with some Tunisians, who escaped during the revolution, I had the opportunity of retracing the moments of their participation in Tunisian riots until their arrival in Italy. From their accounts, the prominence of the body - a power subject-object - has resurfaced. "Body proofs" (Fassin; 2001) have to be exhibited as an incarnated document, which testifies the truthfulness of declarations given to commissions, that evaluate the requests for Political Asylum; as if biology were, for its own sake, not vulnerable to "processes of social construction" (Farmer in Annuary 2006, p. 23).

\subsection{Ibraihm 1st August 2012}

I met Ibrahim at the center of Via Agliè, situated in one of those so-called, Turin suburban neighborhoods; an area meant for urban and social redevelopment.

"I left the North of Tunisia on board an 8-m boat with thirty two other people; all of them men between eighteen and twenty eight, with no food and no water [...] I spent all my time in prayer, I am a Muslim, I was very scared because it was my first time of crossing. I had decided to leave since we couldn't live comfortably due to poverty. For three months

\footnotetext{
${ }^{26} \mathrm{http}: / /$ www.youtube.com/watch?v=wSm4WRBjV74

${ }^{27}$ Arthur Kleinman, Chapter 5 "Medical Anthropology and Mental Health: Five Questions for the Next Fifty Years", in Marcia Inhorn, eds., 2012.

${ }^{28}$ The boys who immigrated to Turin through chance trips, with the passeur, or under trucks, identify themselves in the term "harrâga", which means "burned" (from the verb to burn, to cut off, to leave). Precisely, they are those that burn. They burn from desire, they burn down the boundaries within which they feel constrained, assuming the risk to die out completely. (Master's graduation thesis by Alice Rossi 'Etnografia della violenza strutturale tra minori e giovani marocchini a Porta Palazzo', Università degli Studi di Milano-Bicocca, 2007/2008).

${ }^{29}$ Young, graduated Tunisian who, to survive, had to be a stallholder. He set himself on fire on December 17th, 2010 in front of the local Governor's building, following the confiscation of his goods by the police.

$30 \mathrm{http}: / / \mathrm{ww}$.controappuntoblog.org/2012/08/23/due-suicidi-col-fuoco-a-torino/.
} 
during the war I did not work because the war had destroyed my work. My cousin, the son of my mother's sister, died. He was a mechanic; a good friend of mine. We were always together after work"

To my question: "What do you think of the war?", Ibraihm answered: "we need twenty more years to change things. All those, who used to work for the regime, can do whatever they want to today. They are free [...].Whatever is happening, is a movie, it is not the truth, what you see on TV is not true. I believe all Tunisian journalists lie. Today there is the same Ben Ali system. There is still war. Yesterday a friend of mine phoned. In a village, two people died because of racism... Since there is no work any more, the locals have become racists against the internal migrants coming from another village. Talking about the hogra feeling, he explained to me: "It is someone who doesn't think of others. But you have hogra here as well, without my fellow countrymen I wouldn't do anything here. Only a few Italians helped me... I am at the second renewal of my permit to stay on grounds of temporary protection, since I arrived before the 5th April 2011. Now that l've found a job, the renewal will be on working grounds but I have to pay $€ 450$ in contributions. During the war, only two things existed. You either live or you die. In the war I lost my cousin and my job. It is as if I had lost my youth. I cannot go back to Tunisia; you need at least two years. My cousin has been killed by a gunshot perhaps by the police, who are the most corrupt. Every policeman owns four places where to live, three cars and hegets his shopping through the taxi drivers, who otherwise get fined. The poor stays poor. At the beginning of the war I believed in the change but afterwards I lost everything because I realized that, even though Ben Ali was no longer there, everything else had remained unchanged".

Ibrahim has no faith in the revolution and he is rather disillusioned by life conditions he found in Italy. He cannot go back because his cousin's murderer has been arrested and he fears retaliations by that family. In Italy, he has to pay taxes instead of his employer in order to have the guarantee of a permit to stay on working grounds. And he lives in a sort of double absence (Sayad; 1999) one of those who lives "neither here nor there".

In the collected stories, frequent events of self-mutilation emerged on the part of those Tunisian, so-called "rebutted" migrants, kept at the C.I.E. for identification and expulsion. These are resistance practices, as a dialectic answer to tangible attempts of dispossession of one's reacting capacity (Pizza; 2005). The said behaviour can also be read in the light of what James Clifford defines as displacement practices, constituting cultural meanings, that is capable of actively producing cultural meanings (Pizza; 2005).

\subsection{Ajej, Moroccan, unaccompanied ex-minor, 15th February 2012}

"I stayed at C.I.E. for two months. I got out because of this knock in my eye, I hurt myself... so I left to go to hospital and from there, they could not keep me. At C.I.E. they always give you rice and put medicines in your food to keep you quiet. After eating, we always felt sleepy. They put Rivotril in there so you eat and you sleep... I recognized it because I used to get high on it, outside. My Tunisian friend has been repatriated with a broken rib, another one tied his arm, cut himself and spattered the bathrooms, blood everywhere..."

It has to be noted how these practices, for example, the swallowing of razor blades, of self-inflicting deep cuts onto one's arms, of swallowing batteries, bear the objective of obtaining hospitalization because, this being an administrative restrain, it is not possible to force the person to go back, once he is out of the camp. In fact, the C.I.E. is not classified as a detention area; on the contrary, migrants are defined by law as "guests". Therefore one could say that, in this case, physical pain is more of a life strategy; functional towards freedom and escape, than a practice of resistance. The body is an element to be manipulated in order to escape or to produce the proofs required for the acknowledgement of your status as Applicant for Politic Asylum, as it has been confirmed by a general practitioner, who visited the migrants hosted in C.A.R.A. (Centers for Reception of Asylum Petitioners).

Detention of Maghrebis in the Italian C.I.E. corresponds to a political choice, related to the rebut easiness based on agreements for re-admittance. Moreover, according to the Caritas Dossier 201131, the Moroccans represent the majority of those, who do not obey the expulsion and the C.I.E. in Turin is populated by Tunisians, together with Moroccans and Egyptians.

Jamal, a Tunisian thirty-eight-year-old man, arrived after the 5th of April. He has submitted a Politic Asylum request, but he must produce some proof of the death threats, he claims, he had suffered. His body has no wounds, his family in Tunisia undergoes continuous harassment and intimidations because of his participation in revolution events. In spite of all this, for the evaluating commission, he is an economic migrant, who illegally entered Italy, thus he can be expelled.

${ }^{31} \mathrm{http}: / /$ www.caritasitaliana.it/pls/caritasitaliana/v3_s2ew_Consultazione.mostra_pagina?id_pagina=404 
The C.I.E.32. is a contemporary form of "camp", a bio-political paradigm of Modernity (Agamben; 1995), situated inside the town. It is made invisible by high walls, hiding it from the passer-by's gaze, whilst the so-called "cages" - the enclosures where the migrants live in small, separated houses - are open. This total visibility, accessible only from above, is for those responsible for the Red Cross, great pride in comparison with other existent structures in Italy and in Europe. In the recounts of those, who had instead been there, the C.I.E. appears to be a space where "social suffering" (Kleinman, Das, Lock; 1996) duplicates; where power hierarchies, which exist outside the walls, are repeated - between those who have money and those who don't - and where the relations between identity and memory alter themselves (Fabietti, 1995; Fabietti, Matera, 1999; Beneduce, 1993; Halbwachs, 1968; Assmann, 1999), thus generating out-of-focus and fragmented perceptions of oneself and of one's own context of origin. In this total institution (Goffman; 1961), clandestineness and illegality re-produce themselves (De Genova; 2004). The Centers of identification and expulsion in Italy are places where rights are suspended, which de-politicize the concept of trauma, transforming it into an issue of police control and citizen safety.

\section{Conclusions}

"The subjectivity of the free man becomes subjugation: on one side, the submission to the other through control and dependence [...], on the other side the "attachment" to one's own identity through the conscience and knowledge of the self, with all the techniques of moral sciences and human sciences, which will give way to a knowledge of the subject" (Deleuze 1987, p. 104)

Hogra as a trans-national feeling crossing over different geographic areas, but also the history of various Countries since the colonial era up till the new-born colony of the Turin metropolis. The violence of the colonial system seems to be able to still tell us something today; within the system of capitalist economy, which again presents the dichotomous logic of exclusion and inclusion. The street boys in Turin or Tangiers stray on the edges of movement forms, or they get recruited into the troops of regime supporters; as has been denounced during the present protests in Morocco. Explicit, physical and psychological violence and tangible freedom encaging reflect the colonial logic, which becomes a natural item like that occurring in the C.I.E.

Often, we speak about adaptation without reflecting on the theme of incorporation; there is no body as a place separated from the mind, but a "mindful body" (Scheper Hughes, Lock; 1987). A body-full-of-mind is therefore full of context, relations, history, reconstructed memories and, as in the case of highly controversial dynamics - involving life and death spheres - the body-fills-up-with violence. With this interpretation, violence has an enticing power; that which draws violence, as it has been seen in the history of dissidence in the North of Morocco up till the present-day; protest forms, of which the suicides through fire are the extreme expressions. The present 20F Movement links activists, local political bodies, migrants and global nets. Migration, in itself is a potential form of dissidence and becomes a means of transmission and transformation of protests, which locally redefine themselves, in Tangiers as in Turin. Notwithstanding the interest of media and politics for the strong participation at Beni Makada and the recent debut of the 20F Movement in Turin, during my research no explicit connection came into sight between the anger of those living in an extremely marginalized condition - like the Moroccan street boys - and those who give vent to through protests. Polyphony and the contradictory alliances of Moroccan activism in Tangiers are amazing compared with the silence among Turinese migrants. In this latter case, what seems to "inhibit" the auto-reflective faculties depends on life conditions in a context of arrival and migratory path-types. According to an immigrated activist, "The difference between the Arab Spring and the Moroccan Spring is not a matter of quality but a degree in dissident management by the monarchy. Reforms have been taking place since the end of Hassan II's reign... this has been appeasing, at least in the form..." (18 $8^{\text {th }}$ January 2013)

My perception of contemporary dissident forms is that they are sparked off within a logic founded on the capacity of the Makhzen to take advantage of its own dissidents today, as it has been in past history: "... if the effect of protests has been that of pushing the king towards constitutional reform, the Movement should thus be thanked! The king is a good guy, we, the Moroccans, love him..." (7 $7^{\text {th }}$ July 2011, a Beni Makala girl; not a supporter of the 20F Movement).

32 "The C.I.E. in Italy represent the legal dimension of the "camp", which, within the theoretical frame of consideration proposed by Agamben (1995, p. 186), is a "modern-type nomos". The camp, not emanating from common rights but from a status of an exception and from the martial law, finds its legal basis in the Schutzhaft (protection custody); a legal institution of Prussian origin, which allowed for "taking people in custody" irrespectively of any criminally-relevant comportment and with the sole aim of precluding danger towards State security [...]" (Master's graduation thesis by Alice Rossi 'Etnografia della violenza strutturale tra minori e giovani marocchini a Porta Palazzo', Università degli Studi di Milano-Bicocca, a.a. 2007/2008, p. 82). 
In the evaluation of the formation processes of activists' subjectivity, various levels of analyses have to be taken into account. They involve, as we have already seen, biographic, contextual, historical-economic, political aspects and, last but not least, religious values.

Forms of fracture and continuity with the past history cross over society and generations, sometimes contrasting activists and parents loyal to the king-father-figure. The accusation of "treacherous atheist" is a disgrace on the entire family. In other cases, instead, the parents' militancy is transmitted on to their children, with those forms of coercion and intimidation, going on in the family schemes and in the collective memory (Halbwachs; 1968), from generation to generation.

Social suffering (Kleinman, Das, Locke; 1997) that surfaces from the imagery and practices of some migrants in Turin - even though issues might appear to be remote from the real political struggle - is the result of the intersecting political, economic and institutional powers.

Consequently, some forms of migrant dissidence allow for better interpretation from the viewpoint of their generative power to produce other perceptions rather than those of politically explicit-and-conscious forms of dissidence. As is the case of embodied practices of resistance and life-strategy in the C.I.E. or the hybrid and heterogeneous emerging forms of religion and secularism.

\section{References}

Agamben G. (1995), Homo sacer. II potere sovrano e la nuda vita, Torino, Einaudi.

Annuario di Antropologia. (2006) Sofferenza sociale. A cura di Ugo Fabietti. Roma, Meltemi. Anno 6 n. 8.

Asad T. (2003), Formations of the Secular. Christianity, Islam, Modernity, Stanford, Calif.: Stanford University Press,192.

Assmann A. (1999), Erinnerungsraume. Formen und Wandlungen des kulturellen Gedachtnisses, Munchen, C.H. Beck'sche Verlagsbuchhandlung (trad. Ita. Paparelli S. Ricordare. Forme e mutamenti della memoria culturale, II Mulino Bologna, 2002)

Austin J. L. (1991) Quand dire c'est faire, tard. fr. J. Lane, Seuil, Coll. 'Points-Essais', Paris.

Beaumont, J. 2010. 'Transcending the particular in postsecular cities'. In Molendijk, Beaumont, and Jedan (eds). Exploring the Postsecular: the religion, the political and the urban, Leiden/ Boston: Brill.

Beneduce R. (1993), Geografie della memoria. Considerazioni clinico - antropologiche su migrazione e salute mentale, in Passaggi di confine. Etnopsichiatria e migrazioni, a cura di V. Di Micco e P. Martelli, Napoli, Liguori.

Beneduce R. (1998), Frontiere dell'identità e della memoria, F. Angeli, Milano.

Beneduce R., (2007), Etnopsichiatria. Sofferenza mentale e alterità fra Storia, dominio e cultura, Carocci, Roma

Bennafla K. (2009), Fabrication et sens des marges au Maroc: les mobilisations de périphérie au Maroc: les cas de Sidi Ifni et Bouarfa (2009), Centre Jacques Berque, Rabat.

Bennafla K. ; Emperador M. (2010) Le Maroc inutile redécouvert par l'action publique : le cas de Sidi Ifni et de Bouarfa, Politique Africaine, $n^{\circ} 120, p$ 67-86

Bourdieu P., (1972), Esquisse d'une théorie de la pratique, Paris, Droz (ed. it. Per una teoria della pratica. Con tre saggi di etnologia qabîla, Milano, Cortina. 2003).

Bourgois, P. (2005) Cercando rispetto : drug economy e cultura di strada . Roma, Derive Approdi

Butler J. (1993), Bodies that matter : on the discursive limits of sex, London, Routledge (ed. it::1996, Corpi che contano: i limiti discorsivi del sesso, Milano, Feltrinelli).

Casanova J. (2009) Exploring the post-secular: three meanings of 'the secular' and their possible transcendence. Paper presented at New York University, 22-24 Oct

Clifford J., Marcus (1986) Writing culture: The Poetics and Politics of Etnography, Berkeley. University of California Press

Csordas T. J. (1999), Perspectives on embodiment. The intersections of nature and culture, a cura di G.Weiss, F.H. Haber, London, Routledge pp. 143 - 162 (ed it Incorporazione e fenomenologia culturale. in Annuario di Antropologia: Corpi. nº 3 pp. 19-42. Meltemi, Roma, 2003)

Debord G.E. (1967) The Society of the Spectacle, Zone Books 1995

De Genova N. (2004), .La produzione giuridica dell.illegalità. II caso dei migranti messicani negli Stati Uniti, in Mezzadra S. (a cura di), I confini della libertà. Per un.analisi politica delle migrazioni contemporanee, Roma, DeriveApprodi, pp. 181-215.

Fabietti U. (1994), Sceicchi, beduini e santi. Potere, identità tribale e religione nel mondo arabo-musulmano, Milano, Angeli

Fabietti U. (1995). L'identità etnica. Carocci editore, 2008, Roma.

Fabietti U., Malighetti R., Matera V., (2002), Dal tribale al globale introduzione all'antropologia, Mondadori, Milano

Fabietti U., Remotti F., Scarduelli P., (1989), Centri, ritualità, potere. Significati antropologici dello spazio, II Mulino, Bologna.

Fanon F. (1956). Razzismo e cultura, Comunicazione al primo congresso degli scrittori e degli artisti neri. Sorbonne: Parigi, 12-19 Settembre. Ed. it., «Razzismo e cultura». In Fanon 1, opere scelte a cura di Pirelli, G.. Torino: Einaudi, 1976.

Fanon F. (1961), Les damnés de la terre, Paris, Maspéro/La Découverte \& Syros (ed. it.: 2000, I dannati della terra, Torino, Edizioni di Comunità).

Fanon F., (1952), Peau noire masques blancs. Edition du Seuil. Ed it. : Pelle nera e maschere bianche. 1996. Ed . Tropea. Milano

Farmer P. (2003), Pathologies of Power. Health, Human Rights, and the New War on the Poor, Berkeley - Los Angeles - London, 
University of California Press.

Farmer P. (2006), Un antropologia della violenza strutturale. In annuario antropologia: Sofferenza sociale. $n^{\circ} 8$ pp.17 - 50. Meltemi, Roma.

Fassin D. (2009), Les economies morales revisitées. Etude critique suivie de quelques propositions, Annales. Histoire, Sciences Sociales, 64 (5), sous presse.

Fassin D., (2001), The Biopolitics of Otherness. Undocumented Foreigners and Racial Discrimination in French Public Debate, "Anthropology Today", 17, 1, pp. 3-7;(ed. It. 2006, "La biopolitica dell'alterità. Clandestini e discriminazione razziale nel dibattito pubblico in Francia", in Quaranta 2006, pp. 303-322)

Foucault M. (1975) Surveiller et punir. Naissance de la prison, Paris, Gallimard (ed. it.: 1976, Sorvegliare e punire. Nascita della prigione, Torino, Einaudi).

Foucault M. (1976), La volonté de savoir, Paris, Gallimard (ed. it.: 2008, La volontà di sapere. Storia della sessualità 1, Milano, Feltrinelli).

Foucault M. (1976), La volonté de savoir, Paris, Gallimard (ed. it.: 2008, La volontà di sapere. Storia della sessualità 1, Milano, Feltrinelli).

Foucault M. (1980), "Two Lectures", in Gordon C., Power/Knowledge. Selected Interviews and Other Writings, 1972-1977, New York, Harvester Weatsheaf.

Foucault M. (1982), The Subject and the Power, Chicago, University of Chicago Press (ed. it:: 1989, II soggetto e il potere, Firenze, Ponte alle Grazie).

Foucault M. (1988) Technologies of the self. A seminar with Michel Foucault. A cura di Luther H. Martin, Huck Gutman, Patrick H. Hutton. The university of Massachusetts Press, Amherst. (ed. It. Un seminario con Michel Foucault. Tecnologie del sé. Torino, Bollati Boringhieri 1992).

Gandolfi P. (2010), La sfida dell'educazione nel Marocco contemporaneo, Città Aperta ed., Troina (En).

García B.L. (2011), Marruecos ante el proceso de cambios en el mundo árabe, Área: Mediterráneo y Mundo Árabe ARI 46/2011 Fecha.

Geertz C. (1968), Islam Observed. Religious Development in Morocco and Indonesia, Yale, Yale University.

Gigliotti G. (2005), Esperienze Internazionali. Tunisia, n.14, Spinn-Italia Lavoro S.p.A, Roma.

Goffman E., (1961), Asylums. Essay on the social situation of mental patients and other inmates, Published by arrangement with Doubleday, a division of the Doubleday Broadway Publishing Group, a division of Random House, Inc. (Ed. Ita. Le istituzioni totali: I meccanismi dell'esclusione e della violenza, ed. di Comunità, Torino, 2001 )

Habermas J. (2002) Religion and Rationality: Essay on Reason, God, and Modernity, Cambridge MA: the MIT Press

Habermas J. (2006) Religion in the Public Sphere, European Journal of Philosophy 14, 1-25

Halbwachs M. (1968) La mémorie collective, Presses Universitaires de France, Paris

Hammoudi A. (2001), Maîtres et disciples. Genèse et fondements des pouvoirs autoritaires dans les sociétés arabes. Essai d'anthropologie politique, Maisonneuve et Larose - Editions Toubkal, Paris - Casablanca.

Hibou B. (2011), Anatomie politique de la domination, La Découverte, Paris.

Hibou B. (2011), Le mouvemente du 20 fevrier, le Makhzen et l'Antipolitique. L'impense des reformes au Maroc, SciencesPo, CERI CNRS.

Hibou B., Tozy M. (2009), La lutte contre la corruption au Maroc : vers une pluralisation des modes de gouvernement?', Droit et Société, 72.

Hobsbawm E. J. et Ranger T. D. (1983), The invention of tradition, Cambridge, Cambridge University Press.

Kleinman A., Das V. e Lock M. (editors) (1997), Social Suffering, Berkeley-Los AngelesLondon, University of California Press.

Mbembe A., (2005), Post-colonialismo, Meltemi.

Osella F., Soares B. (2010) Islam, Politics, Anthropology, Wiley-Blackwell, Royal Anthropological Institute.

Passerini L. (2003), Memoria e utopia : il primato dell'intersoggettivita, Bollati Boringhieri, Torino.

Pizza,G. (2005), Antropologia medica. Saperi, pratiche e politiche del corpo, Roma,Carocci, 2005.

Quaranta I. (2006 b) Introduzione. Annuario antropologia: sofferenza sociale. n8 pp 5-16. Meltemi, Roma.

Quaranta I. (2007) Corpo, memoria e violenza, in AChAB - Rivista di Antropologia Numero X - Febbraio 2007 pp. 2 - 7.

Sayad A. (1999), La double absence, Paris, Seuil (ed. it.: 2002, La doppia assenza. Dalle illusioni dell'emigrato alle sofferenze dell'immigrato, Milano, Cortina).

Scheper-Hughes N., Lock M. (1987) ."The Mindful Body: A Prolegomenon to Future Work in Medical Anthropology". Medical Anthropological Quarterly, n. 1 (1), pp. 6-41

Scott J., (1983), 'The Moral Economy of the Peasant: Rebellion and Subsistence in Southeast Asia', Paperback, (ed. Ita: 'I contadini tra sopravvivenza e rivolta', Liguori, 1983)

Thompson E.P. (1971), The Moral Economy of the English Crowd in the Eighteenth Century, Past \& Present, No. 50 , Published by: Oxford University Press.

Tozy M., (1999), Monarchie et Islam Politique au Maroc, Presses de Sciences Politiques, Paris

Vermeren P. (2002), Ecole, élite et pouvoir au Maroc et en Tunisie au XX siècle, Alizés, Rabat.

Vertovec S.(1999), Conceiving and Researching Transnationalism, "Ethnic and Racial studies", 2, no. 2, pp. 447-62

Wacquant L. (2004) Punir les pauvres. Le nouveau gouvernement de l'insécurité sociale. Agone, Paris (Ed It.. Punire i poveri. II governo dell'insicurezza sociale. Roma, Derive e Approdi 2006)

Kleinman A. (1986), Social Origins of Distress and Disease: Neurasthenia, Pain and Depression in Modem China. New Haven: Yale 
University Press.

Riccio, B. (a cura di), 2008, Migrazioni transnazionali dall'Africa, Torino, UTET.

Rossi A. (2012) Moroccan minors and the internal frontiers of undocumented migration (Turin, Northern Italy, 2003-2009), Mediterranean Journal of Social Sciences, Vol. 3, No. 8; Conference Proceedings ICHSS 2012 